\title{
CCNE1 Gene Mutation
}

National Cancer Institute

\section{Source}

National Cancer Institute. CCNE1 Gene Mutation. NCI Thesaurus. Code C157382.

A change in the nucleotide sequence of the CCNE1 gene. 